DOI: https://doi.org/10.47405/mjssh.v6i8.981

\begin{tabular}{|c|c|}
\hline 4 & Malaysian Journal of Social Sciences and Humanities (MJSSH) \\
\hline $\begin{array}{l}\text { Malaysian Juoural of } \\
\text { Social ccciecces and }\end{array}$ & Volume 6, Issue 8, August 2021 \\
\hline (MJ-sSH) & e-ISSN : 2504-8562 \\
\hline & $\begin{array}{l}\text { Journal home page: } \\
\text { www.msocialsciences.com }\end{array}$ \\
\hline
\end{tabular}

\title{
The Influence of Sustainable Product's Attributes Toward the Willingness to Pay for Sustainable Product
}

\author{
Marlita Rexa Lestari' ${ }^{1}$, Arfenia Nita ${ }^{1}$ \\ ${ }^{1}$ School of Business and Management, Bandung Institute of Technology, Indonesia \\ Correspondence: Marlita Rexa Lestari (marlita_rexa@sbm-itb.ac.id)
}

\begin{abstract}
As a result of this growing concern for environmental issues, a new market for sustainable products has emerged, with engaged consumers driving it even further. It influenced the new trend and resulted in new behaviors in their daily lives, resulting in a more sustainable lifestyle. Several studies on sustainability have increased year after year, including sustainable products, which are on the rise. This study aims to determine the contribution of sustainable product's attributes on customers' willingness to pay more for sustainable products, mainly to assist the sustainable industry in developing strategies that correspond with the values of sustainable products and also sustainable product consumer values. This study was carried out using quantitative methods using online surveys distributed to respondents who fit the criteria, had an interest in sustainable products, and live in Indonesia. This study resulted in 204 respondents who have used or intend to use sustainable products, dominated by respondents who live in Bandung and Jabodetabek. To identify and analyze the attributes that influence the willingness to pay more for a sustainable product, the researcher uses Structural Equation Modelling (PLS-SEM) to process the survey findings. The results of this study is the willingness to pay more towards sustainable products significantly affected by eco-label, eco-packaging, and local production. From these variables, local production is the key variable that influences customers to spend extra money for sustainable products. This findings demonstrates that the suggested model contributes to the literature and is valuable for understanding in depth the attributes that motivate potential customers to pay more for sustainable products. As a result, companies can get recommendations on how to establish effective marketing campaigns.
\end{abstract}

Keywords: attributes, sustainable products, willingness to pay more

\section{Introduction}

Based on the UNEP projection, the generation level of MSW tends to increase year to year (UNEP, 2016). While in the United Nations Report of Waste Management in ASEAN Countries, Indonesia became the first producer of Municipal Solid Waste (MSW) in ASEAN with a total of 64 million tonnes per year (UNEP, 2017). Over time, the increasing human population will increase the amount of existing waste. Because the amount of material demand consumed by the community will increase and if this is not managed properly it will have an impact on various fundamental aspects, such as health and the environment (Amirah, 2012), such as blockage of waterways resulting in flooding, marine pollution, the spread of disease, respiratory problems from burning garbage, barriers in the tourism sector (World Bank Group, 2018). 
We, as the consumer and/or the producer, have the power to minimize this problem through our consumption and/or production, as mentioned in Sustainable Development Goals number 12: Responsible consumption and production. Based on a survey that was conducted by IBM, from baby boomers until gen $\mathrm{z}$ has scored $75 \%$ or more toward sustainable/environmentally responsible, it shows us that they care about sustainable responsible in their consumption (IBM, 2019).

A new market for sustainable products has formed as a result of this rising concern toward environmental issues, and engaged consumers have increased it more significantly. The rationale for this is that consumer's active participation is seen as a strategy of promoting for protecting the environment (Shabbir et al., 2020).

Consumers and communities are increasingly purchasing green products (Singh, 2020). Because green products are still in their infancy stage in Indonesia (Alamsyah et al., 2020), companies need to implement marketing strategies such as advertising and taking attributes on green products (Tiwari et al., 2011). It is supported by Jeevandas (2019), that every individual must take a step forward for the environment in order to achieve sustainable development. One of them is green marketing that benefits both the consumer and the market since the green products are beneficial not just to the environment but also to humans. Yazdanifard et al. (2011) stated consumers want to associate themselves with firms that are environmental stewards, therefore if it communicates its commitment to the environment through marketing, sales promotions, and others, it is sure to gain many loyal customers.

However, green products are considered to be more expensive than conventional products due to the production process. That is why the attribute is critical for improving profitability by attracting ecoconscious customers who are willing to pay more in order to support a more expensive manufacturing process (Dubihlela et al., 2016); Crespi 2006). Therefore, it is important for companies to know better what attributes affect the willingness to pay more for green products than conventional products of potential customers, in order to increase the sales of green products.

\section{Literature Review}

\section{Sustainable Products}

A sustainable lifestyle means prioritizing the use of goods derived from resources that are more environmentally friendly to prevent natural exploitation that should be maintained for the next generation because actually, nature is for them (Danielle, 2019). Sustainable Product is similar to a traditional product, but has a minor negative effect on the environment due to the energy required to make it environmentally sustainable, and has the potential to preserve the environment because it can be recycled and has a range of environmental benefits (Biswas, 2016). This is supported by Moser (2016), that green product is less harmful or not at all harmful to the environment. Green products are becoming increasingly popular nowadays, they come in a variety of forms such as organic veggies and organic fertilizer (Wirth, 2011; Alamsyah 2020).

\section{Willingness to Pay More for Sustainable Product's Attributes}

Willing to pay (WTP) is defined as the price a buyer is willing to pay for a given quantity of a good or service. The environmentally conscious buying behavior of customers can significantly affect the market performance of products consequently, there is a strong demand to examine customer preference attributes when they make buying decisions. The customer markets for environmentally friendly goods and services are expected to grow for several years (Anil et al., 1999). Within the present context, consumers' willingness to pay for environmentally friendly products could be perceived as a green purchase intention that reflects an individual's consideration of less pollution and readiness to perform green purchase behavior (Chen and Deng, 2016). There is a huge positive impact of sustainable products on the willingness to pay consumers (Wang et al., 2021). A study by Saravanaraj (2017) shows customer's preference for various attributes of green products, variables that assist respondents to identify products as "green". 


\section{Eco-label Attribute}

As mentioned by Min et al. (2017), the adoption of eco-labels on items is beneficial since they provide consumers with important information. The researchers mentioned that eco-label preferred groups are willing to pay a premium for eco-labels (Liu, 2017). Eco-labels have the potential to boost consumer's willingness to spend $16-24 \%$ extra on a product (Vitale et al., 2020)

\section{Eco-Packaging Attribute}

Producers should concentrate on four main variables of green packaging: environment, quality, commodity, and price (Hao, 2019). There are several studies that found most of the participants are willing to pay more for products that use eco-friendly packaging, that is $86 \%$ of participants of the study in Sweden (Lindh, 2016), 81\% of participants of the study in the United States (Neill, 2016), and $67 \%$ of participants of the study in Germany (van Birgelen, 2009).

\section{Local Production Attribute}

There are several attributes which organic, fair trade, carbon footprint, and location claim that were investigated by Onozaka and McFadden (2010). They also discovered that local products offer the highest willingness to pay value for consumers. Feldmann and Hamm (2015) investigated consumer perceptions and preferences for local products. They discovered that consumers are willing to pay more for local products because they want to support the local community.

\section{Conceptual Framework and Hypotheses}

This research is using a customer value creation framework that developed by Smith and Colgate (2007), shown in Figure 1. The following is the relationship between variables: Environmental has direct and indirect relation on willingness to pay more for sustainable products that has Eco-label and Eco-packaging as antecedents. Also Eco-label, Eco-packaging, and Local Production have influences on Willingness to Pay more for sustainable products.

Figure 1: Conceptual Framework

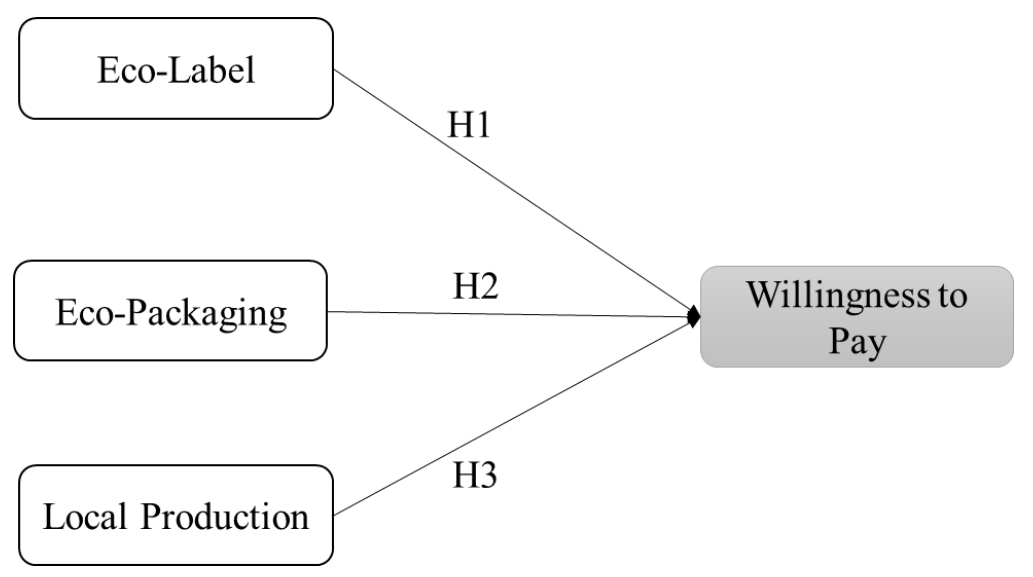

H1: Eco-label positively influence the willingness to pay for sustainable products

$\mathrm{H} 2$ : Eco-packaging has positively influenced the willingness to pay for sustainable product

H3: Local products positively influence the willingness to pay for sustainable products 


\section{Methodology}

\section{Research Design}

The objective of this research is to analyze the attributes of the sustainable product that are considered the most by the customer that make the customer willing to pay for the sustainable product. The first step is to conduct problem identification that determines the issues that customers faced when they come to purchase some sustainable products. Then the next step is doing a literature review to look deeper for the previous research that relates to the topic. After that, the researcher constructed a questionnaire to be given to the proposing respondents. The data will be gathered using quantitative methods and analyzed using Structural Equation Modeling (SEM). The final step is to conclude the findings and create a recommendation regarding the topic.

\section{Population}

The target of this study is people, both men or women, that live in Indonesia who tend or are interested to use the sustainable product, especially on consumer goods. Based on the book titled Marketing Research: An Applied Approach wrote by Malhotra \& Birks (2005), the sample size is the number of elements that will use in the study that should be between 200 and 400 respondents for a marketing study.

\section{Sampling Techniques}

The sampling technique used by the researcher is non-probability sampling, more precisely purposive sampling because the researcher has determined the criteria of the respondent. Purposive sampling is a non-probability sampling method in which the researcher chooses the elements for the sample based on the evaluation. The researchers believe that by applying the purposive sampling they can produce a representative sample and save time and money (Black, 2010).

\section{Data Collection}

An online questionnaire, using a google form, was spread to collect the primary data for this study. The author chose an online questionnaire since it can collect data more quickly, at a lower cost, and with a wider range of responders (Sekaran \& Bougie, 2016). The respondents need to fill out all of the questions asked in the questionnaire. The questions ask about the attributes that influence them when they will purchasing the sustainable product. The questionnaire will be delivered using Bahasa Indonesia because the proposing respondents are people who use Bahasa Indonesia as their first language. The researcher uses online messenger and social media to spread their questionnaire.

Table 1. Distribution of Respondent Demographics

\begin{tabular}{lll}
\hline Variable & Category & Frequency \\
\hline Gender & Male & $94(46 \%)$ \\
& Female & $110(54 \%)$ \\
Domicile & Bandung & $82(40 \%)$ \\
& Jabodetabek & $60(29 \%)$ \\
\multirow{2}{*}{ Level of Education } & Others & $62(31 \%)$ \\
& Bachelor Degree & $151(74 \%)$ \\
& Master Degree & $23(11 \%)$ \\
& Senior High School & $22(11 \%)$ \\
& Others & $8 \quad(4 \%$ \\
\hline
\end{tabular}

\section{Data Analysis}

In this study, Partial Least Square (PLS) was utilized to ensure that the correlation model for each variable in the model was correct. SmartPLS was utilized by the researcher of this study to examine 
the association between all variables. To assess the measurement model, there are several steps needed to be conducted, this began with the creation of a conceptual model and data processing using the PLS method and bootstrapping.

\section{Results}

\section{Convergent Validity}

The average variance extracted (AVE) value of each variable can be used to determine the convergent validity. If the AVE value is more than 0.5, the variables should be accepted and valid (Wong, 2013). ). In Table 2 below, the AVE values are more than 0.5, also the outer loadings are greater than 0.7, therefore all the items in the questionnaire are valid based on convergent validity.

Table 2. Convergent Validity

\begin{tabular}{|c|c|c|c|c|c|}
\hline Variable & Item & Questionnaire & $\begin{array}{l}\text { Outer } \\
\text { Loadings }\end{array}$ & $\begin{array}{l}\text { Average } \\
\text { Variance } \\
\text { Extracted } \\
\text { (AVE) }\end{array}$ & Indicator \\
\hline \multirow[t]{3}{*}{$\begin{array}{l}\text { Eco- } \\
\text { Packaging }\end{array}$} & EP1 & $\begin{array}{l}\text { I pay attention to the } \\
\text { environmental friendly } \\
\text { aspect of the packaging } \\
\text { of products I buy }\end{array}$ & 0.791 & 0.739 & Valid \\
\hline & EP2 & $\begin{array}{l}\text { I will choose to buy } \\
\text { product with green } \\
\text { packaging }\end{array}$ & 0.893 & & Valid \\
\hline & EP3 & $\begin{array}{l}\text { I am willing to buy a } \\
\text { product with recyclable } \\
\text { packaging }\end{array}$ & 0.891 & & Valid \\
\hline \multirow[t]{4}{*}{ Eco-Label } & EL1 & $\begin{array}{l}\text { Eco-label makes me more } \\
\text { aware of the use of these } \\
\text { products }\end{array}$ & 0.868 & 0.695 & Valid \\
\hline & EL2 & $\begin{array}{l}\text { Eco-label makes me } \\
\text { understand more about } \\
\text { these products }\end{array}$ & 0.871 & & Valid \\
\hline & EL3 & $\begin{array}{l}\text { Eco-label makes me more } \\
\text { confident in these } \\
\text { products }\end{array}$ & 0.831 & & Valid \\
\hline & EL4 & $\begin{array}{l}\text { I would prefer to check } \\
\text { the eco-labels and } \\
\text { certifications on green } \\
\text { products before purchase }\end{array}$ & 0.761 & & Valid \\
\hline $\begin{array}{l}\text { Local } \\
\text { Production }\end{array}$ & LP1 & $\begin{array}{l}\text { I prefer to buy products } \\
\text { from small local } \\
\text { producers in preference } \\
\text { to those from large or } \\
\text { international producers }\end{array}$ & 0.874 & 0.783 & Valid \\
\hline
\end{tabular}


DOI: https://doi.org/10.47405/mjssh.v6i8.981

\begin{tabular}{|c|c|c|c|c|c|}
\hline & LP2 & $\begin{array}{l}\text { I always try to look for } \\
\text { locally made products } \\
\text { during each purchase }\end{array}$ & 0.871 & & Valic \\
\hline & LP3 & $\begin{array}{l}\text { I purchase locally grown } \\
\text { to support local business }\end{array}$ & 0.909 & & Valid \\
\hline \multirow[t]{4}{*}{$\begin{array}{l}\text { Willingness } \\
\text { to Pay More } \\
\text { for } \\
\text { Sustainable } \\
\text { Product }\end{array}$} & WTP1 & $\begin{array}{l}\text { Compared with ordinary } \\
\text { non-green products, I am } \\
\text { more willing to pay extra } \\
\text { to buy Sustainable } \\
\text { Products }\end{array}$ & 0.877 & 0.719 & Valic \\
\hline & WTP2 & $\begin{array}{l}\text { I pay extra for eco- } \\
\text { labeled products, i.e., } \\
\text { non-polluting products }\end{array}$ & 0.884 & & Valid \\
\hline & WTP3 & $\begin{array}{l}\text { I am proud to use the } \\
\text { product with green } \\
\text { packaging, even though it } \\
\text { is more expensive than } \\
\text { the conventional } \\
\text { packaging }\end{array}$ & 0.755 & & Valid \\
\hline & WTP4 & $\begin{array}{l}\text { I should be willing to pay } \\
\text { more for local product }\end{array}$ & 0.869 & & Valid \\
\hline
\end{tabular}

\section{Discriminant Validity}

Discriminant validity can also be used to assess validity. It is a measure of a variable's uniqueness in capturing phenomena in comparison to another variable (Hair et al., 2017). Based on Table 3, all the value of Heterotrait-Monotrait Ratio is less than 0.9, therefore we can conclude that there is no issue in the discriminant validity.

Table 3. Heterotrait-Monotrait Ratio

\begin{tabular}{lllll}
\hline & EL & EP & LP & WTP \\
\hline EL & & & & \\
EP & 0.699 & & \\
LP & 0.567 & 0.719 & \\
WTP & 0.701 & 0.715 & 0.744 \\
\hline
\end{tabular}

\section{Indicator Reliability}

The indicator reliability test was done to confirm that the construct was stable in relation to how much the objectives wanted to estimate (Urbach \& Ahleman, 2010). As seen in Table 4, all of Cronbach's alpha value is higher than 0.6. While the composite reliability values are also higher than 0.7. Therefore, it means that all variables are considered as reliable. 
Table 4. Indicator Reliability

\begin{tabular}{lllll}
\hline Variable & Item & $\begin{array}{l}\text { Cronbach's } \\
\text { Alpha }\end{array}$ & $\begin{array}{l}\text { Composite } \\
\text { Reliable }\end{array}$ & Indicator \\
\hline Eco-packaging & EP1 & 0.831 & 0.895 & Reliable \\
& EP2 & & Reliable \\
& EP3 & & Reliable \\
Eco-label & EL1 & 0.803 & 0.853 & Reliable \\
& EL2 & & & Reliable \\
& EL3 & & Reliable \\
& El4 & & Reliable \\
Local Production & LP1 & 0.802 & 0.874 & Reliable \\
& LP2 & & Reliable \\
& LP3 & & Reliable \\
& WP1 & 0.882 & & Reliable \\
Willingness to Pay & WP2 & & Reliable \\
Sustainable Product & WP3 & & Reliable \\
& WP4 & & Reliable
\end{tabular}

\section{Hypotheses Testing and Discussion}

Table 5 shows the significant level of each construct. As a result, all of the hypothesis have P-values less than 0.5, and the T-values are above 1.96, therefore those hypotheses are accepted. It means that eco-label, eco-packaging, and local production have direct positive influences on willingness to pay for sustainable products.

Table 5. Hypothesis Testing

\begin{tabular}{lllll}
\hline Hypothesis & $\begin{array}{l}\text { Path } \\
\text { Coefficien } \\
\text { t }\end{array}$ & T Statistic & P Values & Result \\
\hline $\begin{array}{l}\text { H1= Eco-label positively influence the } \\
\text { willingness to pay for sustainable } \\
\text { products }\end{array}$ & 0.301 & 4.766 & 0 & Accepted \\
$\begin{array}{l}\text { H2= Eco-packaging has positively } \\
\text { influenced the willingness to pay for } \\
\text { sustainable product }\end{array}$ & 0.207 & 2.933 & 0.004 & Accepted \\
$\begin{array}{l}\text { H3= Local products positively } \\
\text { influence the willingness to pay for } \\
\text { sustainable products }\end{array}$ & 0.372 & 5.791 & 0 & Accepted \\
\hline
\end{tabular}


The eco-label has a positively related to willingness to pay more for the sustainable products, it supported by Crespi et al. (2005) that stated eco-labels could be created to attract consumers with a high willingness to pay and to provide producers with an incentive. Also supported by Liu et al. (2017) that stated consumers believe that eco-labeled products are healthier and more environmentally friendly. Although it has not high effect, however, it is important to include the eco-labels on the sustainable products to attract consumer's trust (Doszhanov and Ahmad, 2015).

While eco-packaging has the lowest effect than other attributes in this research, however, it also has the positively related with the willingness to pay more for sustainable products. This is supported by Hao et al. (2019) that stated the majority of consumers are concerned about the environment and willing to pay more for products with eco-packaging. There are also several findings that show the willingness of consumers to pay more for products that use eco-packaging such as in Sweden, the United States, and Germany (Lindh, 2016; Neill, 2016; van Birgelen, 2009).

Then for the local products that have a higher influential effect than other attributes on the willingness to pay more for sustainable products. This finding is aligned with Onozaka and McFadden (2010) that local products give the highest value than other several attributes in their research. This is also supported by Feldmann and Hamm (2015) that stated consumers are willing to pay more for local products to help the local community. This shows that besides an eco-conscious, consumers also have a social consciousness. They have both concerns about the environment and society.

\section{Conclusion and Recommendations}

At present, the awareness of Indonesian people is more aware of the importance of protecting the environment. It was impacted by worldwide trends that result in new daily behaviors that apply sustainable lifestyles. Consumer behavior is being influenced by this new behavior. Sustainable products are seen as healthier for humans and the environment. This condition affects the consumer's consumption to start choosing sustainable products.

This research explores and examines the driving attributes of sustainable products that influence consumers on willingness to pay more for sustainable products. All of the three attributes tested showed a significant value, which means that the three sustainable products attributes (Eco-label, Ecopackaging, and Local Products) have significant and positive value on willingness to pay more for sustainable products.

Based on the research results, there are some recommendations that are able to apply in the sustainable products SMEs, especially for those who will open the business in Bandung and Jabodetabek. It is recommended that businesses should pay attention to attributes of sustainable products that have the greatest impact on customer's willingness to pay more for sustainable products. It will allow them to build a successful marketing strategy that will affect their sales.

This study has various limitations that should be considered in future research. For future research, the attributes should be more varied, since this research only studies some of the sustainable product's attributes. This research is also just conducted in Indonesia that dominated by Bandung and Jabodetabek. Therefore, the researcher recommends for future researchers conduct the studies in other areas. Also, this research studies the general generation, the future researcher might study for the specific generation who has the sustainable lifestyle interest. Future research might also study the other industry since this research is only on consumer goods.

\section{References}

Alamsyah, D.P., Othman, N.A., Chung, W.D., Rahila, N., Ibrahim, W., Udjaja, Y. (2020). The Attributes of Eco-Labels : The Sustainability of Customer Green Behavior.

Amirah (2012). Pengaruh Timbunan Sampah di Lahan Terbuka Terhadap Kualitas Air Tanah di 
Sekitar Tempat Penampungan Sampah Semetara Kelurahan Batu Ampar.

Biswas, A. (2016). A Study of Consumers' Willingness to Pay for Green Products. J. Adv. Manag. Sci. 4, 211-215. https://doi.org/10.12720/joams.4.3.211-215

Black, K. (2010). Business Statistics: Contemporary Decision Making. 6th edition, John Wiley \& Sons

Chen, K., Deng, T. (2016). Research on the green purchase intentions from the perspective of Product knowledge. Sustain. 8. https://doi.org/10.3390/su8090943

Crespi, J.M., Marette, S., Cite (2005). Eco-labelling economics: Is public involvement necessary? Environ. Inf. Consum. Behav.

Danielle, C. (2019). What is Sustainable Living?

Doszhanov, A., Ahmad, Z.A. (2015). Customers' Intention to Use Green Products: the Impact of Green Brand Dimensions and Green Perceived Value. SHS Web Conf. 18, 01008. https://doi.org/10.1051/shsconf/20151801008

Dubihlela, J., Peninsula, C., Africa, S. (2016). Customer Attributes and the Repurchase. Int. Bus. Econ. Res. J. 15, 163-175.

Feldmann, C.; Hamm, U. (2015). Consumers' perceptions and preferences for local food: A review. Food Qual. Prefer, 40, 152-164

Hao, Y., Liu, H., Chen, H., Sha, Y., Ji, H., Fan, J. (2019). What affect consumers' willingness to pay for green packaging? Evidence from China. Resour. Conserv. Recycl, 141, 21-29. https://doi.org/10.1016/j.resconrec.2018.10.001

Lindh, H.; Olsson, A.;Williams, H. (2016). Consumer perceptions of food packaging: Contributing to or counteracting environmentally sustainable development? Packag. Technol. Sci., 29, 3-23

Liu, Q., Yan, Z., Zhou, J., (2017). Consumer choices and motives for eco-labeled products in China: An empirical analysis based on the choice experiment. Sustain, 9. https://doi.org/10.3390/su9030331

Min, S.H., Lim, S.Y., Yoo, S.H. (2017). Consumers'willingness to pay a premium for eco-labeled LED TVs in Korea: A contingent valuation study. Sustain, 9. https://doi.org/10.3390/su9050814

Moser, A.K. (2016). Consumers' purchasing decisions regarding environmentally friendly products: An empirical analysis of German consumers. J. Retail. Consum. Serv., 31, 389-397. https://doi.org/10.1016/j.jretconser.2016.05.006

Neill, C.L.; Williams, R.B. (2016). Consumer preference for alternative milk packaging: The case of an inferred enviromental attribute. J. Agric. Appl. Econ., 48, 241-256

Onozaka,Y;; Nurse, G.; Thilmany McFadden, D. (2010). Defining Sustainable Food Market Segments: Do Motivations and Values Vary by Shopping Locale? Am. J. Agric. Econ., aaq152

Saravanaraj, M.., Pillai, S. (2017). An Analysis of the Green Product Attributes that Entice Green Purchasing- A Study Done in Bangalore City. Int. J. Asian Soc. Sci. 7, 199-205. https://doi.org/10.18488/journal.1/2017.7.3/1.3.199.205

Sekaran, U., \& Bougie, R. (2016a). Research Methods for Business (Seventh Ed). Chichester: Wiley

Shabbir, M.S., Sulaiman, M.A.B.A., Al-Kumaim, N.H., Mahmood, A., Abbas, M. (2020). Green marketing approaches and their impact on consumer behavior towards the environment-a study from the UAE. Sustain, 12, 1-13. https://doi.org/10.3390/su12218977

Smith, J.B., Colgate, M. (2007). Customer value creation: A practical framework. J. Mark. Theory Pract, 15, 7-23. https://doi.org/10.2753/MTP1069-6679150101

Tiwari, S., Tripathi, D.M., Srivastava, U., Yadav, P.K. (2011). Green Marketing - Emerging Dimensions. J. Bus. Excell, 2, 18-23.

UNEP (2017). Summary Report Waste Management 76.

UNEP (2016). GEO-6 Regional Assessment for Asia and The Pacific.

Urbach, N. \& Ahleman, F. (2020). Structural Equation Modeling in Information Systems Research Using Partial Least Squares.

van Birgelen, M.; Semeijn, J.; Keicher, M. (2009). Packaging and proenvironmental consumption behavior. Environ. Behav, 41, 125-146.

Vitale, S., Biondo, F., Giosuè, C., Bono, G., Okpala, C.O.R., Piazza, I., Sprovieri, M., Pipitone, V., (2020). Consumers' perception and willingness to pay for eco-labeled seafood in Italian hypermarkets. Sustain. 12, 1-13. https://doi.org/10.3390/su12041434

WANG, E. peng, AN, N., GENG, X. hui, GAO, Z., KIPROP, E. (2021). Consumers' willingness to pay for ethical consumption initiatives on e-commerce platforms. J. Integr. Agric., 20, 10121020. https://doi.org/10.1016/S2095-3119(20)63584-5 
Malaysian Journal of Social Sciences and Humanities (MJSSH), Volume 6, Issue 8, (page 542 - 551), 2021

DOI: https://doi.org/10.47405/mjssh.v6i8.981

World Bank Group (2018). What a Waste 2.0: A Global Snapshot of Solid Waste Management to 2050. 